\title{
Mekanisme Pasar Dalam Konteks Islam
}

\author{
Sarwo Edi ${ }^{1}$, Julfan Saputra ${ }^{2}$, Asmaul Husna ${ }^{3}$ \\ ${ }^{1}$ Universitas Muhammadiyah Sumatera Utara, Medan, Provinsi Sumatera Utara, \\ Indonesia. \\ 2,3 Universitas Islam Negeri Sumatera Utara, Medan, Provinsi Sumatera Utara, \\ Indonesia.
}

\begin{abstract}
Abstrak. Tulisan ini merupakan literature review yang bertujuan untuk mengetahui mekanisme pasar dalam konteks islam. Metodologi yang digunakan adalab review dari penelitian-penelitian dan buku-buku baik dalam skala lokal Indonesia maupun skala internasional. Berbeda dengan sistem konvensional, konsep Ekonomi Islam menekankan bahwa mekanisme pasar dan penetapan harga perlu diatur untuk mencapai keseimbangan pasar dan keadilan ekonomi dengan mempertimbangkan urgensi para pibak yang terlibat di pasar. Harga yang wajar dan wajar adalah harga yang diperoleh berdasarkan kekuatan penawaran dan permintaan. Dalam hal terjadi tindakan tidak wajar yang mengakibatkan distorsi pasar atau harga tidak berada pada titik ekuilibrium, pemerintab berperan sangat penting dalam mengambil regulasi berupa penetapan harga dengan melihat faktor-faktor penyebab distorsi dan mengembalikan harga. dengan harga aslinya. titik. keseimbangan awal.
\end{abstract}

Kata kunci: Mekanisme Pasar; Penetapan Harga; Penetapan Harga Yang Adil; Distorsi Pasar; Regulasi.

Abstract. This paper is a literature review that aims to determine the market mechanism in the context of Islam. The methodology used is a review of studies and books both on a local Indonesian scale and on an international scale. In contrast to conventional systems, the concept of Islamic Economics emphasizes that market mechanisms and price fixing need to be regulated to achieve market equilibrium and economic justice by considering the urgency of the parties involved in the market. Fair and fair prices are prices obtained based on the power of supply (supply) and demand (demand). In the event of unfair actions that result in market distortions or prices are not at their equilibrium point, the government plays a very important role in taking regulations in the form of price fixing by looking at the factors that cause these distortions and returning prices to the original equilibrium point.

Keywords: Market Mechanisms; Pricing, Fair Pricing; Market Distortions; Regulation.

*Author. Email: sarwoedi@umsu.ac.id ${ }^{1}$,julfansaputra91@gmail.com², asmaul25husna@gmail.com³

DOI: https://doi.org/10.35870/emt.v6i1.477

Received: 14 September 2021, Revision: 7 November 2021, Accepted: 5 December 2021, Available Online: 1 January 2022.

Print ISSN: 2579-7972; Online ISSN: 2549-6204.

Copyright@ 2022. Published by Lembaga Otonom Lembaga Informasi dan Riset Indonesia (KITA INFO dan RISET). 


\section{Pendahuluan}

Ekonomi Islam dalam mekanisme pasar memiliki peran yang amat penting dalam pergolakan kondisi ekonomi negara, terutama di Indonesia. Segala praktik pada pasar sudah sewajarnya menampilkan norma-norma serta nilai-nilai yang sesuai dengan tuntunan agama. Ragam sistem perekonomian yang umumnya dikenal, konvensional, ternyata belum mampu memberikan solusi bagi barometer perekonomian dunia. Ekonomi Konvensional belum memiliki kekuatan dalam mengatur mekanisme pasar yang saat ini berlangsung. Hal yang terjadi mengakibatkan kondisi pasar yang tidak menentu dan berdampak negatif bagi kondisi ekonomi dunia.

Hadirnya sistem ekonomi Islam saat ini ialah melanjutkan sistem ekonomi yang telah ada sejak lebih dari seperempat abad yang lalu. Hal yang umumnya diketahui ialah sistem yang hegemon setelah keruntuhan dari peradaban Islam merupakan sistem ekonomi konvensional kapitalis. Segala aspek kehidupan ekonomi sangat dipengaruhi oleh paham kapitalisme. Dan masa sekarang mulai menunjukkan adanya ketimpangan yang disebabkan oleh paham ekonomi kapitalisme. Paham inilah yang dianggap menyebabkan ketidakmampuan sistem dalam menghadapi krisis ekonomi secara global yang terjadi di dunia. Sehingga sangat dibutuhkan kembali kontribusi ide untuk mengembalikan kondisi ekonomi dalam lingkup aman bebas dari krisis. Hal inilah yang melandasi adanya ide untuk mengembangkan kembali tegaknya sistem ekonomi Islam yang pernah ada di masa lalu. Pondasi sistem ekonomi Islam yang didasari oleh tuntunan AlQur'an dan Sunnah Rasulullah SAW. diharapkan mampu mengembalikan orientasi perwujudan ekonomi yang menjunjung keadilan dan kesejahteraan.

Hadirnya sistem ekonomi Islam bukanlah hal yang baru dalam penggunaannya di kehidupan manusia. Akan tetapi kajian keilmuan khusus yang membidangi ekonomi Islam masih tergolong muda. Penerapan perekonomian Islami sudah dipakai sejak masa Rasulullah akan tetapi sempat mengalami adanya kemunduran seiring perjalanan waktu yang mengantarkan manusia pada masa seperti saat ini. Namun melihat efektifnya sistem ekonomi Islam di masa lalu maka dapat dijadikan salah satu alternatif sebagai solusi atas kondisi ekonomi saat ini. Kajian dalam bidang ekonomi Islam masih banyak yang dapat dieksplorasi kembali demi kepentingan penyelesaian masalah ekonomi saat ini. Salah satu focus kajian dalam keilmuan ekonomi Islam yang perlu dibahas ialah terkait mekanisme pasar yang ditinjau dalam sudut pandang Ekonomi Islam.

Pasar umumnya menjadi tempat yang paling banyak memperlihatkan aktifitas dan tindakan ekonomi. Proses kegiatan di pasar sederhananya terjadi berlangsung dengan alami tanpa ada sesuatu yang mengintervensi. Akan tetapi, terkadang terjadi kondisi dimana pasar tidak lagi berlangsung sederhana seperti yang umumnya terjadi. Hal yang dapat terjadi adalah adanya kondisi dimana pasar juga mendpat perlakuan intervensi dari beberapa pihak. Sikap ini perlu ditinjau apakah menjadi kondisi yang baik ataukah buruk. Maka pembahasan mengenai mekanisme pasar menjadi topik yang penting untuk dikaji. Selain itu, Sistem ekonomi Islam juga memiliki pola pikir tersendiri mengenai bagaimana Islam memandang aktifitas pasar dalam mekanisme pasar.

\section{Tinjauan Literatur}

Pendefinisian oleh Sa'id Taufiq Ubaid mengenai pasar ialah pasar merupakan media yang berguna sebagai tempat bertemunya antara pihak yang menjual dengan pihak yang membeli. Hal ini bertujuan untuk mendistribusikan barang dan jasa hasil produksi kepada pihak-pihak lain (Amstrong, 1997). Lain hal dengan Roger L Miller dan Roger E. Meiners yang berpandangan bahwa pasar merupakan suatu sistem yang berupaya dalam mengalokasikan sumber daya serta memberikan informasi mengenai nilai relatif mereka. Pasar juga menjadi sistem yang mendistribusikan tiap pendapatan yang senilai dengan niai dari sumber daya yang dipunyai. Keputusan yang terdapat di pasar bersifat terdesentralisasi akibat sistem dari pasar tersebut. Kondisi yang ada di pasar merupakan aktfitas alami atasu spontan yang terjadi dari banyak orang (Meiners, 2000).

Adiwarman A. Karim berpendapat menyerupai Sa’id Taufiq Ubaid mengenai pasar. Menurut 
beliau pasar ialah keadaan dan tempat yang mempertemukan antara permintaan yang dilakukan pembeli dan penawaran oleh penjual bagi tiap-tiap jenis barang dan jasa atau dapat dikatakan sumber daya. Konsumen menjadi pihak yang menginginkan barang atau jasa, sebaliknya bagi industri perlu dan butuh mendapatkan tenaga kerja, modal dan bahan baku barang produksi untuk memproduksi barang maupun jasa. Posisi penjual dalma industri sebagai pihak yang menawarkan barang produksi dan jasa yang ada, sedangkan tenaga kerja sebagai pihak yang membantu terciptanya barang produksi dan jasa (Karim, 2010).

Dalam Al-Qur'an sebagai pedoman hidup, tidak dijelsakan secara rinci mengenai bagaimana pandangan Islam sendiri mengenai mekanisme pasar. Akan tetapi hal ini bukan bermakna bahwa Al-Qur'an tidak membahas kajian ekonomi mengenai pasar. Akan tetapi terdapat dalil dalam Al-Qur'an yang menjelaskan terkait hal ini merujuk kepada aktifitas yang seharusnya di pasar yang perlu kita telaah lebih dalam dengan akal. Dalil ini terdapat dalam Al-Qur'an surat An-Nisa (4) ayat 29 yang artinya sebagai berikut: "Hai orang-orang yang beriman, janganlah kamu saling memakan harta sesamamu dengan jalan yang batil, kecuali dengan jalan perniagaan yang Berlaku atas dasar suka sama-suka di antara kamu. dan janganlah kamu membunuh dirimu. Sesungguhnya Allah Maha Penyayang kepadamu”.

Konsep pasar dalam ekonomi Islam dalam pemikiran Marthon ialah selayaknya didasari oleh etika dan nilai-nilai yang ada dalam hukum syariat. Hal ini meliputi kegiatan yang diperintahkan, pelarangan, hal yang dianjurkan, serta himbauan. Tujuan utama dalam memenuhi kegiatan ekonomi, transaksi, ialah demi mencari ridha Allah Swt. serta mewujudkan kesejahteraan masyarakat dan kemaslahatan umat (Marthon, 2004).

Pasar merupakan perwujudan dari refleksi kemampuan masyarakat dalam memenuhi kegiatan ekonomI demi kebutuhan hidup, dan bukan sebaliknya. Oleh karena itu peran dari produsen, konsumen, serta pemangku kebijakan dalam bidang ini sangat penting dengan tujuan agar dapat menyelaraskan persepsinya terkait keberadaan suatu harga. Jika hal ini terwujud maka dampak dari sistem mekanisme pasar yang baik akan berdampak positif (Sudarsono, 2003).

\section{Pasar Pada Masa Rasulullah}

Peranan penting pasar dalam perekonomian sudah terkonfmasi sejak zaman Rasulullah SAW dan Khulafaurasyidin. Rasulullah SAW dahulu seorang pebisnis begitu pula dengan Khalifah penerus dan para Sahabat. Di masa awal Islam berkembang di Makkah, hal yang menjadi prioritas merupakan dakwah tentang Islam sehingga fokus kepada perekonomian masih belum prioritas. Kondisi ini bertahan sampai masyarakat Muslim pindah ke kota Madinah untuk hijrah dan menetap di sana. Hingga hariharu berikutnya Rasulullah SAW. memberi contoh dengan berperan sebagai pengawas pasar atau disebut Almuhtasib.

Mekanisme pasar sangat dihargai sekali di masa itu. Rasulullah menolak untuk memberikan kebijakan terkait penetapan harga di saat terjadinya lonjakan harga tinggi di madinah. Selama dinamika naik turun harga benar-benar dipengaruhi oleh aktifitas penawaran dan permintaan pasar dan bukan akibat dari monopoli pihak tertentu, maka tidak dibenarkan untuk memberikan intervensi terhadap harga. $\mathrm{Hal}$ ini sesuai sunatullah yang menjelaskan bahwa aktifitas pasar merupakan hukum alam yang harus dihormati.

Melakukan kebijakan penetapan harga tanpa ada alasan yang tepat merupakan suatu hal yang melanggar harga pasar. Tindakan tersebut mencerminkan ketidakadilan di masyarakat yang harus dipertanggungjawabkan di hadapan Allah SWT. Islam sangat menghargai adanya mekanisme pasar murni dalam perniagaan. Oleh sebab itu Islam sangat menjunjung tinggi hak pihak-pihak yang ada di pasar dengan menyebutkan harus adanya kerelaan dan suka sama suka pada aktifitas ekonomi yang berlangsung. Nilai moralitas yang seharusnya ada di pasar ialah sikap kejujuran, persaingan sehat, keterbukaan, dan keadilan.

\section{Pasar Dalam Perspektif Pemikir Muslim Abu Yusuf \\ Dalam buku Abu Yusuf, Al-kharaj, membahas}


tentang prinsip perpajakan dan anggaran negara yang ditujukan sebagai pedoman Khalifah Harun Alrasyid yang berada di Baghdan. Ia memberi kesimpulan bahwa dengan adanya hukum penawaaran dan permintaan akan secara otomatis menentukan tingkatan harga dari barang tersebut, meskipun hal ini tidak dipaparkan secara eksplisit. Lalu terdapat juga dalam bukunya menyatakan bahwa harga tidak hanya ditetapkan oleh penawaran saja namun juga permintaan atas barang tersebut. Ia juga mengindikasi terdapat faktor-faktor lain yang ikut berperan untuk mempengaruhi harga, seperti jumlah uang yang beredar, danya penumpukan sumber daya dan lainnya (Ibrahim, 1979).

\section{Al-Ghazali}

Karya Al Ghazali, Al-Ihya Ulumuddin, mengulas banyak pembahasan mengenai ekonomi. Bukunya juga memuat topik mengenai pasar. Topik mengenai aktifitas perdagangan dan evolusi pasar, kegiatan barter serta permasalahannya, dan juga mengenai kekuatan dari penawaran dan permintaan dalam menetapakan harga.

Kondisi kelemahan dari sistem barter memberikan kesulitan dalam aktifitas ekonomi yang disebut double coincidence. Oleh sebab itu Ia mengatakan perlunya pasar dalam hal ini. Selain itu, Ia memahami suatu konsep yang saat ini kita sebut dengan elastisitas permintaan. Ia mengatakan bahwa dengan mengurangi tingkat margin keuntungan untuk mengurangi harga jual akan mampu meningkatkan jumlah barang terjual yang akhirnya akan meningkatkan keuntungan lebih cepat.

\section{Metodologi Penelitian}

Penelitian ini menggunakan metode penelitian kualitatif berdasarkan studi kepustakaan (library research) (Moleong, 2006). Penelitian ini dilakukan dengan mengumpulkan artikel buku dan jurnal dengan tema sesuai dengan tujuan penelitian yaitu Struktur pasar dalam pandangan Islam Sumber data primer diperoleh dari seluruh karya yang ditulis langsung oleh tokoh pemikir ekonomi Islam, Sementara sumber data sekunder, diambil dari karya-karya ilmiah yang terkait dengan topik pembahasan, ditambah dengan tulisan-tulisan dalam disiplin ilmu ekonomi Islam yang dibantu oleh software Publish or Perish untuk menghimpun artikel jurnal yang relevan dan selanjutnya melakukan analisis isi (content analysis). Analisis konten merupakan suatu teknik penelitian untuk menghasilkan deskripsi yang objektif dan sistematik mengenai isi yang terkandung dalam media yang diteliti (Zuchdi, 1993).

Teknik ini dilakukan melalui tiga tahapan yaitu; pertama tahap reduksi data yakni data yang diperoleh dari artikel jurnal dilakukan reduksi, dirangkum dan dipilih hal-hal yang pokok dan difokuskan pada hal-hal yang penting serta disusun secara sistematis sesuai dengan tujuan penelitian agar data tersebut menjadi lebih mudah dipahami dan dikendalikan. Kedua display data yaitu menampilkan merupakan informasi yang diperoleh sebagai hasil dari reduksi data yang memungkinkan adanya penarikan kesimpulan dan pengambilan data sesuai dengan tujuan penelitian. Ketiga Penarikan Kesimpulan atau Verifikasi di mana peneliti mencari makna dari data yang dikumpulkan dan melakukan penarikan kesimpulan yang lebih mendasar sesuai dengan tujuan penelitian (Moleong, 2006).

\section{Hasil dan Pembahasan}

Mekanisme pasar umumnya terkait dengan masalah keseimbangan dalam kegiatan pasar. Kondisi seimbang atau equilibrium menggambarkan situasi dimana kekuatan dari penawaran dan permintaan dalam posisi yang seimbang. Kondisi ini akan membentuk variabel harga dan kuantitas tidak berubah lagi di pasar. Keadaan ini menyebabkan harga dan kuantitas yang seimbang dan transaksi terjadi. Perubahan dalam keseimbangan harga di pasar bisa melalui 3 (tiga) bentuk perubahan yang berasal dari permintaan oleh pembeli, penawaran oleh penjual, penawaran dan Permintaan oleh kedua belah pihak.

Dalam persaingan pasar tekadang terdapat kondisi dimana ada pihak yang tidak adil dalam kegiatan ekonomi. Hal ini menjadikan harga yang muncul tidak mencerminkan competition market price (McKenzie, 1983). Beberapa hal tersebut ialah; 1) Manipulasi informasi demi meraih keuntungan lebih (Tadlis). Hal ini termasuk 
dalam praktik penipuan. Tadlis dapat terjadi dalam hal kualitas barang, kuantitas ukuran atau takaran, atau harga, 2) Perbedaan pengetahuan diantara penjual dan pembeli. Memanfaatkan ketidaktahuan konsumen pada barang yang dijual (ghaban faa hisy), dan 3) Melakukan kolusi antara penjual dan pembeli yang sebenarnya adalah koleganya demi menipu harga pasar.

Jumbur ulama juga sepakat bahwa dalam keadaan darurat dapat menjadi alasan pemerintah mengambil kebijakan intervensi harga, tetapi tetap berpijak kepada keadilan (Frank, 2003). Secara umum kondisi darurat yang dimaksudkan ialah kondisi dimana; 1) Kenaikan harga yang sangat tinggi dan tidak wajar yang menyebabkan daya beli masyarakat tidak tercapai, 2) Terkait barang yang menjadi bahan pokok masyarakat. Seperti bahan pangan, dan 3) Adanyaeksploitasi dan ketidakadilan diantara pelaku ekonomi.

\section{Solusi Islam Menghadapi Ketidaksempurnaan Bekerjanya Pasar Larangan Ikbtikar}

Praktik menimbun dan menahan barang dengan sengaja atau disebut dengan ikhtikar sangat dilarang oleh Rasulullah SAW. Praktik ini akan membuat kondisi kelangkaan pada barangbarang yang ditimbun. Kelangkaan ini diharapkan dapat menaikkan harga jual pada barang yang ditimbun di kemudian harinya. Kondisi ini dapat mengakibatkan kerugian bagi masyarakat luas karena kesulitan dalam menemukan barang tersebut. Untuk dapat kembali ke harga semula maka pemerintah perlu melakukan upaya memberantas ikhtikar tersebut. Namun, kondisi ikhtikar tidak termasuk apabila kondisi pasokan barang ynag ditimbun melimpah.

\section{Membuka Akses Informasi}

Larangan terhadap praktik penipuan merupakan upaya dalam melakukan keterbukaan informasi Beberapa larangan terhadap praktik penipuan pada dasarnya adalah upaya untuk menyebarkan keterbukaan informasi sehingga transaksi dapat dilakukan dengan sama-sama suka dan adil. Larangan mengenai hal ini antara lain: talaqis rukhban (membeli barang dengan mencegat para penjual sebelum sampai di tujuan penjualan), bay najasyi (praktik kolusi dantara penjual dengan kolega untuk menipu pembeli lain), ghaban fahisy (upaya mengaburkan informasi memanfaatkan ketidaktahuan konsumen demi keuntungan tinggi.

\section{Regulasi Harga}

Bila pasar telah berlangsung sempurna maka tidak ada celah untuk ikut mengintervensi tingkat harga di pasar. Intervensi harga malah akan mendistorsi harga dan pada akhirnya akan mengganggu mekanisme pasar. Maka, regulasi harga hanya dapat dilakukan di situasi yang dibutuhkan saja atau dalam keadaan darurat. Hal itupun dilakukan demi kemaslahatan masyarakat. Pemerintah dapat melakukukan regulasi harga hanya jika terdapat atau terindikasi adanya pasar yang tidak seimbang dan keadaan darurat. Apabila terpaksa untuk membuat kebijakan terhadap ketetapan harga pasar, maka harga yang telah diintervensi haruslah menjadi harga yang adil bagi semua pihak.

\section{Telaah Kritis Mekanisme Pasar}

Adam Smith dalam ekonomi konvensional menyatakan bahwa "Dengan cara mengerahkan produksi maka akan mampu mengerahkan produksi yang dapat menghasilkan nilai yang terbesar. Dia hanya berniat untuk keuntungan diri sendiri, Hal seperti itu digerakkan oleh tangan yang memandunya. pada batas yang tidak ia kehendaki." (Smith, 1937). Singkatnya, Adam Smith menjelaskan bahwa meski semua orang mealkukan sesutua demi kepentingan pribadi namun hasilnya akan dapat dirasakan keefektifannya yang selaras dengan tujuan masyarakat. Dampak aktivitas setiap individu dalam mengejar kepentingannya masing masing terhadap kemajuan masyarakat akan lebih baik dibandingkan semua orang ingin mensejahterakan masyarakat.

Filosofi Smith ini mendapatkan kritik dari Karl Marx. Marx menganggap karena ide-ide Smith hanya akan menguntungkan para pemilik modal dan memunculkan sistem kelas. Marx memiliki pemikiran yang bertentagan dengan ide mekanisme pasar yang diusung Adam Smith. Menurut (Deliarnov, 2006) terdapat tiga poin alasan, yaitu; 1) Dalam kondisi ekonomi Laissez faire mendorong surplus value dan kekayaan yang dikuasai sebagian orang saja, 2) Secara psikologi 
kondisi ini menimbulkan adanya sistem kelas. Perselisihan muncul antara kelas si kaya dan kelas si miskin, dan 3) Secara sosial masyarakat akan terbagi menjadi dua golongan, yaitu tuan tanah dan buruh.

Dinamika dari sistem ekonomi konvensional dalam memberikan pemikiran dalam bidang ekonomi tidak diikuti dengan solusi dalam kegagalannya di hal-hal tertentu. Ekonomi konvensional belum mampu memberikan sistem yang menjunjung nilai keadilan dan etika dalam praktiknya. Segala hal bersifat parsial akibat orientasi sistemnya bermuara pada hal duniawi. Perihal regulasi dalam menetapkan harga yang dikenal dalam dunia Figh, sikap menentukan harga ini disebut dengan tas'ir yang artinya menetapkan harga tertentu terhadap barang yang dijualbelikan dengan tetap tidak menzhalimi pihak yang melakukan transaksi jual beli (Sabiq, 1995).

\section{Kesimpulan}

Pasar merupakan tempat paling ramai dalam melakukan aktifitas ekonomi dimana kegiatan ekonomi berlangsung secara alami. Ekonomi Islam berpendapat bahwa mekanisme pasar karena adanya pihak-pihak yang melakukan permintaan dan penawaran di pasar. Mekanisme pasar dalam perspektif ekonomi Islam pada prinsipnya ialah menolak terhadap adanya intervensi terhadap harga pasar dalam keadaan pasar berjalan sebagaimana mestinya dan tidak ada kendala apapun terkait ketetapan harga di pasar. Namun, dalam kegiatan ekonomi di pasar maka diharuskan adanya sikap-sikap yang menjunjung tinggi moralitas yaitu melakukan persaingan secara bebas, bersikap jujur, adanya keterbukaan, dan menjaga keadilan. Bila value tersebut ada dalam pasar maka harga yang ada dapat diterima. Sebaliknya bila penyimpangan moralitas dilanggar maka kewajiban pemerintah untuk turun tangan mengatasi kondisi darurat yang terjadi. Hal ini demi menjaga kemaslahatan dan kesejahteraan masyarakat.

\section{Daftar Pustaka}

Amstrong, P. K. (1997). Prinsipprinsip.Pemasaran. Jakarta: Penerbit Erlangga.

Deliarnov. (2006). Ekonomi Politik: Mencakup Berbagai Teori.dan Konsep yang Komprehensif. Jakarta: Erlangga.

Frank, R. M. (2003). Micro Economics and Behavior. London: Routledge.

Ibrahim, A. Y. (1979). Kitab al-Kharaj. Beirut: Dar al- Ma'rifah li ath-Thiba'ah.wa anNasyr.

Karim, A. A. (2010). Ekonomi.Mikro.Islami . Jakarta: Rajawali.Pers.

Marthon, S. (2004). Ekonomi Islam di Tengah krisis.Ekonomi Global. Jakarta: Zikrul Hakim.

McKenzie, R. B. (1983). The Limit of Economic Science. Kluwer. Kluwer: Nijhoft Publishing.

Meiners, R. L. (2000). Teori.Mikro. ekonomi Intermediate. Jakarta: PT Raja.Grafindo.Persada.

Moleong, j. L. (2006). PT. Remaja Rosdakarya. Bandung: PT. Remaja Rosdakarya.

Sabiq, S. (1995). Fiqhus Sunnah. Beirut: Syirkatu Manariad-Dauliyah.

Smith, A. (1937). An Inquiry Into The Nature and Causesiof the Wealth of Nations. New York: The Modern Library.

Sudarsono, H. (2003). Konsep Ekonomi.Islam, SuatuPengantar. Get. II. Yogyakarta: Ekonisia.

Zuchdi, D. (1993). Panduan Penelitian Analisis Konten. Yogyakarta: Lembaga Penelitian IKIP Yogyakarta 